\title{
PENGALAMAN PUTUS OBAT PADA KLIEN TB YANG MENDAPATKAN PENGOBATAN OAT DENGAN STRATEGI DOTS DI RS UMUM KABUPATEN TANGERANG TAHUN 2016
}

\section{(Experience of Drop Out of Medicine on TB Clients That Getting OAT Treatment with DOTS Strategy in Tangerang District General Hospital)}

\author{
Nuraini $^{1}$, Naziah $^{2}$, Muhammad Arifki Zainaro ${ }^{3}$ \\ ${ }^{1}$ Dosen Prodi Ilmu Keperawatan Fakultas Ilmu Kesehatan, Universitas Muhammadiyah \\ Tangerang \\ ${ }^{2}$ Dosen Prodi Ilmu Keperawatan Fakultas Ilmu Kesehatan, Universitas Nasional Jakarta \\ ${ }^{3}$ Dosen Akademi Keperawatan Malahayati Bandar Lampung \\ E-mail : anney.passolong@gmail.com
}

\begin{abstract}
ABSTRAK
Penelitian ini bertujuan untuk mendapatkan informasi yang mendalam tentang pengalaman putus obat pada Klien TB yang mendapatkan pengobatan OAT dengan strategi DOTS dan mengeksplorasi faktor pendukung dan penghambat. Penelitian ini menggunakan desain penelitian kualitatif dengan pendekatan fenomenologi, dengan jumlah informan 8 orang, diantaranya 4 orang putus obat dan 4 orang yang tidak putus obat. Informan kunci adalah keluarga klien sebanyak 8 orang. Data yang diperoleh dianalisis dengan pendekatan Colaizzi. Hasil penelitian didapatkan sembilan tema yaitu; pengetahuan penyakit $\mathrm{TB}$, riwayat kesehatan, dukungan keluarga, penyuluhan TB, manfaat pengawas menelan obat, obat tuberculosis, efek samping obat TB, dampak/resiko putus obat TB, Sikap terhadap pengobatan TB. Saran diperlukan peningkatan kemampuan dalam memberikan pendidikan kesehatan, membuat leaflet dan diberikan pada saat klien berobat dan peneliti lanjutan dengan fenomenologi untuk menggali pengalaman putus obat secara sfesifik.
\end{abstract}

Kata kunci : Pengalaman, Putus Obat, TB, Pengobatan OAT, Strategi DOTS

\begin{abstract}
This study aimed to obtain in-depth information about the experience of withdrawal to the Client OAT TB treatment with DOTS strategy and explore the enabling and inhibiting factors. This study used a qualitative research design with a phenomenological approach, with the number of informants 8 people, including 4 people drop out of medicine and the 4 people who did not drop out of medicine. The key informant was the client's family as much as 8 people. The data obtained were analyzed by using Colaizzi approach. The result showed nine themes, namely; knowledge of TB disease, medical history, family support, counseling $T B$, the benefits of a treatment supporter, tuberculosis medicines, the side effects of TB medicines, the impact / risk of dropping out of TB drugs, attitudes against the TB treatment. Suggestion is need to improve the ability to provide health education, made a leaflet and given upon the client treatment and continued with the
\end{abstract}


phenomenology researchers to explore the experience drop out of medicine in specifically.

Keywords : Experience, Breaking up drug, TB, treatment of OAT, DOTS Strategy

\section{PENDAHULUAN}

Tuberkulosis paru (TB Paru) adalah suatu penyakit infeksi yang disebabkan oleh Mycobacterium tuberculosis. Bakteri ini merupakan bakteri basil yang sangat kuat sehingga memerlukan waktu lama untuk mengobatinya. Bakteri ini lebih sering menginfeksi organ paru-paru (90\%) dibandingkan bagian tubuh lain manusia (Achmadi, 2010).

Menurut WHO (2010), penyakit tuberkulosis suatu penyakit global emergency. TB paru adalah suatu penyakit yang juga mempunyai angka kematian yang tinggi secara global. Pada tahun 2013 WHO memperkirakan ada 8,6 juta kasus baru TB (13\% merupakan koinfeksi dengan HIV) dan ada 1,3 juta orang meninggal karena tuberkulosis dimana diantaranya 940.000 orang dengan HIV negatif dan 320.000 orang dengan HIV dan tuberkulosis positif (WHO, 2013).

Default (Putus obat) merupakan salah satu penyebab terjadinya kegagalan pengobatan yang berpotensi meningkatkan kemungkinan terjadinya resistensi terhadap obat anti TBC (Manaf, 1999). Penelitian di Spanyol dengan judul "Kepatuhan Pengobatan Tuberkulosis dan kematian di Spanyol" oleh Caylà et al pada tahun 2009, diketahui bahwa diantara kasus angka kejadian default di wilayah itu sebesar 1,8\%. (Caylà et al, 2009).

Berdasarkan data dari WHO pada tahun 2012. Indonesia merupakan peringkat keempat negara dengan kasus TB tertinggi setelah Negara China, India, dan Afrika Selatan (WHO, 2013). Di Indonesia penyakit TB adalah pembunuh nomor satu di antara penyakit menular dan merupakan penyebab kematian nomor tiga setelah penyakit jantung dan penyakit pernapasan akut pada seluruh kalangan usia (Riskesdas, 2013). Prevalensi TB paru berdasarkan diagnosis dan gejala TB paru menurut provinsi, di Indonesia 2013. Banten berada di urutan kelima dengan TB paru tertinggi dengan persentase $(0.4 \%)$ setelah Jawa Barat (0.7\%), Papua (0.6\%), DKI Jakarta (0.6\%), dan Gorontalo (0.5\%) (Rikesdas, 2013).

Dari hasil Identifikasi data klien putus obat (default) TB Rawat Jalan Poli Klinik Paru - DOTS di RSU kabupaten Tangerang 2015 pada tri wulan pertama (I) 30 Klien (29.7\%), tri wulan kedua (II) 38 Klien $(30.2 \%)$, tri wulan ketiga (III) 43 Klien (32.6\%), dan tri wulan keempat (IV) sebanyak 66 Klien (38.6\%).

Penanganan penyakit TB dilakukan secara komprehensif dari penemuan kasus hingga pengobatan pada pasien TB. Tanpa pengobatan, angka kematian akibat TB menjadi tinggi. (WHO, 2013). Selain untuk menyembuhkan pasien dan mencegah kematian, tujuan pengobatan TB lainnya yaitu mencegah kekambuhan, memutuskan rantai penularan, dan mencegah terjadinya resistensi kuman terhadap Obat Anti Tuberkulosis (OAT) (Kemenkes RI, 2011). Penanggulangan dengan strategi DOTS (Directly Observed Treatment Shortcourse) dapat memberikan angka kesembuhan yang tinggi dan berkontribusi untuk meningkatkan harapan hidup dan memperpanjang umur penderita (BBKPM, 2008).

Kesembuhan yang ingin dicapai diperlukan keteraturan berobat bagi setiap penderita. Panduan OAT jangka pendek dan peran Pengawas Minum Obat (PMO) merupakan strategi untuk menjamin kesembuhan penderita. Keberhasilan 
pengobatan tuberkulosis paru ditentukan oleh kepatuhan dan keteraturan dalam berobat, pemeriksaan fisik, dan laboratorium (Roestam, 2000 dan Dalianto, 1999). Pada masa pengobatan diperlukan kerja sama yang baik serta berkesinambungan antara seorang PMO dengan penderita dalam mematuhi peraturan tata cara minum obat dan kontrol kesehatan (Widjanarko dkk, 2006).

Salah satu akibat dari ketidakteraturan minum obat adalah resistensi. Resistensi obat terjadi karena pengobatan jangka panjang, dan klien berhenti minum obat saat merasa sudah lebih baik, atau akibat dari permasalahan kesehatan lainnya, seperti penyalahgunaan obat (Black \& Hawks, 2014).

Diperkirakan seorang penderita tuberkulosis paru dewasa akan kehilangan rata-rata waktu kerjanya 3 sampai 4 bulan, hal tersebut berakibat pada kehilangan pendapatan tahunan rumah tangganya sekitar 20-30\%. Jika meninggal akibat penyakit tuberkulosis paru, maka akan kehilangan pendapatannya sekitar 15 tahun, selain merugikan secara ekonomis, Tuberkulosis paru juga memberikan dampak buruk lainnya secara sosial bahkan kadang dikucilkan oleh masyarakat (Depkes RI, 2008). Kerugian yang diakibatkan oleh penyakit tuberkulosis paru bukan hanya dari aspek kesehatan semata tetapi juga dari aspek sosial ekonomi, dengan demikian tuberkulosis paru merupakan ancaman terhadap cita-cita pembangunan dalam meningkatkan kesejahteraan rakyat secara menyeluruh. Karenanya perang terhadap penyakit tuberkulosis paru berarti pula perang terhadap kemiskinan, ketidakproduktifan dan kelemahan akibat tuberkulosis (Depkes RI, 2008).

\section{METODE}

Penelitian ini menggunakan desain penelitian kualitatif dengan pendekatan fenomenologi, Pendekatan ini di pilih agar pengalaman Informan dapat dieksplorasi menjadi lebih terungkap sehingga gambaran pengalaman putus obat pada penderita TB yang mendapatkan pengobatan OAT dengan strategi DOTS dapat tergambar secara nyata. Selain itu penelitian ini melakukan instuting, analyzing dan describing secara langsung fenomena pengalaman-pengalaman para pasien yang bercerita tentang kejadian putus obat pada penderita TB yang mendapatkan pengobatan OAT dengan strategi DOTS dengan sebebas mungkin dari sebuah instuisi yang tidak bisa diukur secara langsung.

Penelitian ini dilakukan pada bulan Mei 2016. Identifikasi Informan dilakukan di Ruangan Rawat Jalan di Poli Klinik Paru (TB-DOTS) Rumah Sakit Umum Kabupaten Tangerang. Adapun tempat pelaksanaan wawancara disesuaikan dengan keinginan Informan. Informan dalam penelitian terdiri dari Informan 8 orang, diantaranya 4 orang putus obat dan 4 orang yang tidak putus obat dan Informan kunci sebanyak 8 orang (keluarga klien yang bertugas sebagai pengawas menelan obat). Pemilihan Informan dalam penelitian ini ditetapkan secara langsung (purposive sampling).

Pengumpulan data dilakukan secara bertahap yaitu dimulai dari uji coba pedoman wawancara, kemudian melakukan wawancara mendalam. Setelah selesai kemudian dilanjutkan dengan observasi terkait dengan jenis, cara, waktu, dosis/jumlah, dan sisa obat pada Informan, yang terakhir dilakukan wawancara mendalam pada Informan Kunci.

Pengolahan dan analisis data dilakukan sejak awal pengumpulan data. Pengolahan dan analisa data dilakukan dengan metode Fenomenologi yang dikembangkan oleh Colaizzi (1987) dalam Strubert \& Carpenter, 2000). Tahapan analisis meliputi: (1) Membuat transkrib data (proses verbatim dari alat perekam suara) untuk mengidentifikasi pernyataanpernyataan yang bermakna dari Informan dengan memberi garis bawah; (2) Membaca transkrip dengan teliti dan berulang 
kemudian memberikan kode-kode data dari setiap pernyataan Informan yang memiliki ide yang berbeda; (3) Membuat kategorisasi pernyataan-pernyataan; (4) Setelah mengkategori semua pernyataan kemudian mengelompokkan kategori tersebut menjadi satu pernyataan-pernyataan yang saling berhubungan satu dengan yang lainnya; (5) Konfirmasi ulang dengan Informan tentang data yang dihasilkan dan meminta pendapat Informan apakah data sudah sesuai dengan apa yang mereka alami; (6) Menambahkan data tambahan jika ada dari hasil komfirmasi sehingga data menjadi lengkap.

\section{HASIL}

Hasil karakteristik diperoleh bahwa: 4 Informan mengalami Putus obat dan 4 Informan Tidak mengalami Putus Obat. Informan dilakukan wawancara sebanyak satu kali dan satu kali validasi data, bahasa yang digunakan adalah bahasa indonesia. Rentang umur Informan antara 15 tahun sampai 55 tahun. Informan yang berjenis kelamin laki-laki 4 orang diantaranya 2 orang yang mengalami putus obat dan 2 orang tidak mengalami putus obat. sedangkan yang berjenis kelamin perempuan berjumlah 4 orang diantaranya 2 orang yang mengalami putus obat dan 2 orang tidak mengalami putus obat. Informan memiliki pendidikan rendah 2 orang dan pendidikan tinggi 6 orang. Pendapatan Informan kurang dibawah UMK Kota Tangerang 4 orang dan diatas UMK Kota Tangerang 4 orang. Klasifikasi penyakit informan berfariasi yaitu paru, tenggorokan, kelenjar dan tulang. Berat badan informan antara $42 \mathrm{Kg}$ sampai dengan $65 \mathrm{Kg}$. Semua informan melakukan tes BTA dengan Hasil Positif (+). Informan kunci adalah keluarga klien TB berjumlah 8 orang.

Hasil dari analisis didapatkan Sembilan tema. Tema-tema tersebut adalah : Tema Pertama : pengetahuan penyakit TB. Pengetahuan penyakit TB pada klien TB diuraikan dalam tiga sub tema yang diantaranya penyebab TB, gejala TB, cara penularan TB.

Sebagian informan dapat menjelaskan penyebab TB secara umum dengan benar, informan menjelaskan bahwa penyebab penyakit TB adalah kuman yang masuk dan menepel diparu-paru. Semua informan mempunya gejala yang berbeda-beda dan mengatakan bahwa mengetahui tanda tersebut dari apa yang dialami dan dirasakan oleh informan sendiri. Informan berpendapat TB menular melalui udara. Bahkan beberapa informan menambahkan menghirup udara yang kotor, batuk-batuk, berbicara terlalu dekat dapat menyebabkan penularan TB ke orang lain. Beberapa informan mengungkapkan bahwa tidak mengetahui tentang cara penularan TB, berikut pernyataan dari informan;

"saya ga tau itu” (tersenyum) (I7)

"ngak tau juga sih, blom tau, ngak ada yang jelasin" (mengeleng-gelengkan kepala) (I8)

Tema Kedua: Riwayat Kesehatan. Riwayat kesehatan pada klien TB di uraikan dalam empat sub tema yang meliputi kapan mengetahui sakit TB, yang memberi tahu klien sakit TB, penyakit penyerta, tidakan utama ketika mengetahui menderita TB.

Sebagian besar Informan mengungkapkan bahwa pertama kali mengetahui dirinya menderita TB sejak setahun yang lalu (tahun dua ribu lima belas). Semua Informan diberi tahu tentang penyakitnya oleh dokter, beberapa informan menambahkan mengetahui dari rumah sakit umum Tangerang, dan selebihnya mengetahui dari dokter umum dan dokter klinik dekat rumah mereka. Sebagian besar Informan mengungkapkan bahwa tidak memiliki penyakit penyerta, selebihnya Informan mengungkapkan dirinya mempunyai penyakit lain selain TB yaitu HIV, berikut pernyataannya; 
"HIV itu lah, kira kira sejak tahun dua ribu tiga belas" (menatap kebawah, kemudian menatap peneliti kembali) (I5)

Semua informan mengungkapkan bahwa tindakan utama ketika mengetahui menderita TB adalah meminum obat dari dokter. Bahkan informan menambahkan bahwa selain minum obat dari doter juga mengkonsumsi obat herbal, madu, seperti diutarakan informan dibawah ini;

"minum madu, obat herbal yang sudah ada di tempat obat saya beli, saya lupa mereknya... Maksudnya buat stamina"(tersenyum)(I4)

Tema Ketiga: Dukungan Keluarga. Dukungan keluarga di uraikan dalam tiga sub tema yang meliputi hubungan dengan anggota keluarga, yang paling mendukung, yang mendampingi ke RS.

Semua informan mengungkapkan bahwa memiliki hubungan yang baik dengan anggota keluarga. Hubungan yang baik di ungkapkan dalam bentuk support, semangat, dukungan, mengingatkan untuk selalu minum obat, diawasi minum obat, mendukung untuk berobat terus sampai sembuh. Semua informan memperoleh dukungan dari keluarga terdekat seperti bapak, ibu, suami, istri saudara dan anak. Sebagian informan mengungkapkan bahwa selalu didamping oleh anggota keluarga jika ke rumah sakit untuk memperoleh pengobatan, bapak, ibu, anak, bahkan salah satu dari informan juga ditemani oleh kadernya untuk mempermudah dan mempercepat proses pengobatan karena berhubungan dengan kondisi punggung informan yang tidak bisa duduk atau mengantri lama. Berikut pernyataan informan;

\section{“yaaa bapak”(menujuk bapaknya)(II)}

"kader juga ikut nemenin saya, supaya proses ngambil obatnya cepat, soalnya saya ngak bisa duduk lama kan tulang punggung saya sakit..., jadi kalo ada bu rini (kader) lebih enak... Bu rini yang urus pendaftaran dan semuanya, setelah itu kalo sudah dekat giliran saya di panggil masuk baru bu rini nelpon saya buat datang ke rs"(menatap peneliti) (II)

Tema Keempat: Penyuluhan TB. Penyuluhan TB yang dilakukan oleh orang rumah sakit atau tenaga kesehatan diuraikan dalam tiga sub tema yaitu frekuensi ke RS untuk memperoleh pengobatan, informasi tentang penyakit, informasi tentang obat. Beberapa Informan mengungkapkan bahwa ke rumah sakit untuk memperoleh pengobatan yaitu setiap dua minggu sekali, dan ada juga yang mengatakan setiap sebulan sekali. Sebagian informan mengungkapkan bahwa memperoleh informasi dari petugas kesehatan, namun informasi yang diterima informan bervariasi, meskipun demikian informasi yang disampaikan oleh petugas kesehatan berhubungan dengan penyakit dan kondisi yang dialami oleh informan seperti operasi tulang, penularan TB, pengobatan TB yang memerlukan jangka waktu yang lama yaitu enam bulan, pantangan dan anjuran makan. Selebihnya informan mengungkapkan tidak ada informasi yang disampaikan oleh petugas kesehatan kepada informan tentang penyakitnya, bahkan salah satu informan mengungkapkan penyebab dari putus obat karena tidak memperoleh informasi dari petugas kesehatan, berikut pernyataan informan;

"ngak ada, ngasi obat yaudah, nga dijelasin kalo pengobatan TB itu ngak boleh putus dulu juga seperti itu ndak ada yang ngasi tau makanya dulu saya putus karna ngak tau kalo tau saya ngak mungkin lah mutusin obatnya, sekarang juga seperti itu ngak ada yang ngejalasin tapi sekarang saya sudah tau karna pengalaman yang dulu, dan temen temen juga ngasi tau kalo pengobatan ini ga boleh putus, kali ini ngak akan lah saya putus obat insyaallah"(sambil memegang lengan tangannya)(I5) 
pengaruh dari warna obat yang di konsumsi. Selebihnya informan menyatakan bahwa mengalami efek samping dari minum obat yaitu timbul herpes di bagian pinggul dan rasa gatal gatal di sertai nyeri sehingga informan tidak bisa berdiri.

Tema Kedelapan: Dampak/Resiko Putus Obat TB. Sebagain besar informan mengetahui dampak atau resiko dari putus obat, sepeti pengobatan diulang dari awal, pengobatan akan lebih lama lagi, penyakit akan bertambah parah, tetapi meskipun demikian beberapa informan tetap memutuskan pengobatan karena merasa sudah sehat dan tidak akan bermasalah pada dirinya.

Tema Kesembilan: Sikap Terhadap Pengobatan TB. Sikap terhadap pengobatan TB diuraikan dalam dua sub tema dibawah ini keteraturan minum obat dalam jangka waktu yang lama (frekuensi, waktu cara minum obat) dan biaya pengobatan.

Semua informan mengungkapkan setuju dengan ketentuan yang telah di terapkan oleh dokter mulai dari cara minum obat, frekusensi minum obat dan dengan waktu yang lama karna menurut informan itu sudah aturan dan sudah prosedurnya dan harus di dilaksanakan. Sebagian besar Informan menyatakan bahwa tidak keberatan dengan biaya yang di tetapkan karna sudah ada BPJS, beberapa informan mengungkapkan biaya pengobatan dibayar tunai (bayar sendiri) karna tidak mau ikut mengantri lama dan berjam-jam, namun demikian informan tiak keberatan dengan hal tersebut.

\section{PEMBAHASAN}

\section{Gambaran Resiko / dampak dari putus obat.}

Semua informan yang tidak mengalami putus obat mengerti tentang dampak/ resiko dari putus obat yaitu dengan ungkapan pengobatan akan di ulang dari awal, akan lebih lama lagi, penyakit TB akan bertambah parah. Dengan demikian maka secara tidak langsung akan memotivasi informan untuk tidak putus obat sampai waktu di tentukan oleh dokter bahwa informan sudah benar-benar bebas dari TB. sementara untuk informan yang putus obat sebagian besar informan juga mengerti tentang resiko/dampak dari putus obat dengan ungkapan penyakit akan lebih lama, pengobatan akan diulang dari awal, penyakitnya akan bertambah parah, tetapi hal ini tidak cukup untuk memotivasi informan agar tetap menjalankan pengobatan hingga dokter menentukan bahwa informan terbebas dari TB. Satu dari informan yang putus obat mengungkapkan bahwa tidak ada dampak dari putus obat karena ungkapannya berdasarkan pengalaman yang dirasakan dan mengungkapkan hanya putus obat selama satu minggu di fase lanjutan dan langsung mulai minum obat lagi, dengan alasan putus obat bukan karna malas minum tetapi karena waktu jadwalnya konsul kader nya tidak bisa menemani informan karena sibuk dan dengan kondisi tidak bisa duduk lama karena tulang belakang bengkok, sementara bapak nya tidak mengerti untuk mengurus pendaftaran. Masing-masing informan yang putus obat menjelaskan alasan mereka memutuskan pengobatan mulai dari merasa sudah sembuh, napsu makan meningkat, berat barat badan naik, karena tidak memperoleh informasi, kaerna bergantung pada kader, merasa capek ke rumah sakit dengan alasan usia. Satu diantara informan yang putus obat mengungkapkan sudah meraskan dampak dari putus obat dengan mengatakan bahwa penyakitnya bertambah parah dari pengobatan sebelumya, tapi tidak merasa menyesal karena tidak mengetahui dan tidak ada yang memberi tahu.

Pengobatan TB harus lengkap dan teratur sesuai petunjuk sampai dinyatakan sembuh. Bila pasien berhenti menelan obat sebelum selesai pengobatan akan berisiko. Penyakit tidak sembuh dan tetap 
menularkan ke Orang lain, Penyakit bertambah Parah dan bisa berakibat kematian, Kuman menjadi kebal/ tidak mempan terhadap OAT lini pertama (Depkes RI, 2009).

\section{Faktor yang mempengaruhi tidak terjadi putus obat}

Tema; Pengetahuan Penyakit TB. Sebagian besar informan yang mengalami putus obat mengetahui tentang; penyebab TB adalah Kuman Tuberculosis. gejala TB adalah batuk, adanya benjolan, dan tulang menjadi bermasalah. Penularan TB adalah Debu dan udara. Hal ini menunjukkan bahwa pengetahuan informan hanya secara umum tentang penyebab, penularan dan gejala TB. Pengetahuan yang dimiliki informan tidak cukup untuk menyadarkan informan tentang pentingnya pengobatan karena pernyataan yang di sampaikan hanya sebatas pengalaman yang dirasakan oleh informan.

Sebagaimana yang diungkapkan oleh Niven (2008) Pengetahuan merupakan hasil tahu dan ini terjadi setelah orang melakukan pengindraan terhadap suatu obyek tertentu, dari pengalaman dan penelitian terbukti bahwa perilaku yang didasari oleh pengetahuan akan lebih langgeng dari pada perilaku yang tidak didasari oleh pengetahuan.

Hal ini sesuai dengan penelitian yang dilakukan oleh Susilowati (2012), Firdous dkk (2006), Slama et al (2013) disimpulkan bahwa orang yang hanya mempunyai pengetahuan sedikit tentang TB akan memiliki peluang besar untuk terjadi putus obat.

Tema; Dukungan Keluarga. Dalam kondisi kesehatan yang kurang stabil, dukungan keluarga menjadi motivasi penting, dimana semua informan mengungkapkan bahwa memiliki hubungan yang baik dengan anggota keluarga dalam memotivasi informan untuk selalu minum obat secara rutin dan teratur.
Dukungan yang tersebut di peroleh dari anggota keluarga terdekat seperti orang tua (ayah/ibu), suami/istri, anak dan saudara.

Sesuai dengan penelitian yang dilakukan oleh Pare (2013). menyimpulkan adanya hubungan yang signifikan antara dukungan keluarga dengan perilaku berobat pasien TB Paru. Secara statistik menunjukkan bahwa dukungan keluarga merupakan faktor risiko terhadap perilaku berobat pasien TB Paru.

\section{Faktor yang mempengaruhi terjadinya putus obat}

Tema; Riwayat Kesehatan. Sebagian besar Informan mengungkapkan bahwa tidak mempunyai penyakit lain selain TB. satu diantara Informan yang mengalami putus obat mengungkapkan bahwa sedang menderita penyakit HIV. Pasien yang mempunyai penyakit penyerta mempunyai risiko default lebih besar dibandingkan pasien yang tidak mempunyai penyakit penyerta. Hal ini sesuai dengan pernyataan Rian (2010) Pada penelitiannya disimpulkan bahwa terdapat hubungan bermakna antara riwayat kesehatan dengan kejadian default (Rian; 2010).

Tema; Penyuluhan TB. Kelompok pasien yang tidak mendapatkan penyuluhan kesehatan mempunyai risiko besar mengalami default jika dibandingkan dengan kelompok pasien yang mendapatkan penyuluhan kesehatan (Rian, 2010).

Untuk itulah peran petugas kesehatan sangat diperlukan agar penderita tuberkulosis dapat memahami dan sekaligus dapat menjalani proses penyembuhan penyakit tuberkulosis dengan benar (Notoatmodjo, 2002).

Tema; Manfaat Pengawas Menelan Obat. DOTS merupakan metode pengawasan yang direkomendasikan oleh WHO dan merupakan paket pendukung yang dapat menjawab kebutuhan pasien. Pengawas menelan obat (PMO) harus 
mengamati setiap asupan obat bahwa OAT yang ditelan oleh pasien adalah tepat obat, tepat dosis dan tepat interval (Kemenkes, 2013).

Penelitian Firdous dkk, (2006). Adanya hubungan yang bermakna antara ada tidaknya PMO dengan kesembuhan. Orang yang tidak mempunyai PMO akan mempunyai peluang besar untuk mengalami ketidak sembuhan bila dibandingkan dengan orang yang mempunyai PMO.

Tema; Obat Tuberculosis. Pasien yang menerima jenis obat dalam bentuk satuan mempunyai risiko default dibandingkan dengan pasien yang menerima jenis obat kombipak. Menurut cara ambil obat bahwa pasien yang mengambil obat dengan resep mempunyai risiko default dibandingkan dengan pasien yang mengambil obat paket (Rian, 2010).

Panduan OAT kategori-1 dan kategori2 disediakan dalam bentuk paket obat kombinasi dosis tetap (OAT-KDT). Tablet OAT KDT ini terdiri dari kombinasi 2 atau 4 jenis obat dalam satu tablet. Selain itu paket obat Kombipak, paket kombipak ini adalah paket obat lepas yang terdiri dari Isoniasid, Rifampisin, Pirazinamid dan Etambutol yang dikemas dalam bentuk blister (Kemenkes RI, 2014).

Tema; Efek Samping Obat TB. Sebagian besar pasien TB dapat menyelesaikan pengobatan tanpa kejadian tidak diinginkan yang bermakna namun sebagian kecil dapat mengalaminya. Karena itu penting memantau klinis pasien selama pengobatan sehingga efek tidak diinginkan dapat dideteksi segera dan ditata laksana dengan tepat. Pasien yang sehat dapat mencegah efek samping induksi obat. Neuropati perifer seperti kebas atau rasa seperti terbakar pada tangan atau kaki sering terjadi pada perempuan hamil, infeksi HIV, penyalahgunaan alkohol, malnutrisi, diabetes, penyakit hati kronik, gagal ginjal (WHO, 2010 dalam Kemenkes RI, 2013).

Hasil analisis yang dilakukan oleh Rian (2010) terhadapa pengaruh efek samping obat anti tuberkulosis terhadap kejadian default di Rumah Sakit Islam Pondok Kopi Jakarta Timur menunjukkan bahwa adanya keluhan efek samping obat lebih banyak terjadi pada kelompok kasus (default). Pasien TB yang mempunyai keluhan efek samping OAT berisiko untuk mengalami default dibandingkan dengan pasien TB yang tidak mempunyai keluhan efek samping OAT.

Tema; Sikap Terhadap Pengobatan TB. Hasil penelitian lain menyebutkan bahwa terdapat hubungan yang bermakna antara sikap dengan keteraturan minum obat (Ariani, 2015). Sikap yang baik ini berkaitan dengan respon emosional para PMO terhadap stimulus atau obyek (dalam mendukung kesembuhan penderita tuberkulosis paru) positif. Sikap merupakan reaksi respon emosional seseorang terhadap stimuli atau obyek diluarnya yang bersifat penilaian, dan penilaian ini dapat dilanjutkan dengan kecenderungan untuk melakukan atau tidak melakukan sesuatu terhadap stimuli atau obyek (Notoatmodjo, 2002).

\section{KESIMPULAN}

Hasil penelitian ini data disimpulkan bahwa klien yang putus obat dipengaruhi oleh riwayat kesehatan, penyuluhan TB, manfaat pengawas menelan obat, kepatuhan menelan obat $\mathrm{TB}$, efek samping obat TB, sikap terhadap pengobatan TB, sedangkan yang tidak putus obat dipengaruhi oleh, pengetahuan penyakit TB, dukungan keluarga.

\section{SARAN}

Berdasarkan hasil penelitian disarankan untuk meningkatan kemampuan dalam memberikan pendidikan kesehatan, membuat leaflet dan diberikan pada saat klien berobat dan peneliti lanjutan dengan 
fenomenologi untuk menggali pengalaman putus obat secara sfesifik.

\section{DAFTAR PUSTAKA}

Adistha., dkk. (2014). Evaluasi program Pengendalian Tuberculosis ParuDengan Strategi DOTSdi Puskesmas Tanah Kalikedinding Surabaya. Jurnal Brkala Epidemiologi. Vol 2. No. 2.

Ariani. N. W., (2015). Faktor-Faktor Yang Berhubungan Dengan Keteraturan Minum Obat Penderita Tuberkulosis Paru Di Wilayah Kerja Puskesmas Modayag, Kabupaten Bolaang Mongondow Timur.

Black, J.M., \& Hawks, J.H. (2014). Keperawatan Medical Bedah. Edisi 8. Elsevier Mosby

Caylà, Joan. A., et al., (2009). Tuberculosis treatment adherence and fatality in spain. Research Article, Biomed Central, PMC2794858.

Crofton, John., dkk, 2002. Tuberkulosis Klinis Edisi 2. Widya Medika, Jakarta, 2002.

Daniel, O.J., et al., (2006). Default from tuberculosis treatment programme in Sagamu, Nigeria. Pubmed article, PMID 16649455, 2006.

Firdous dkk., (2006). Faktor-faktor penderita tuberkulosis paru putus obat.

Fitri., (2014). Profesi Dokter:Definis, Kompetensi, Dan Tugas Dokter. Info sehat Untuk masyarakat.

Gomes. M. Et al., (2010). Risk Factors for Drug-Resistant Tuberculosis. Journal of Tuberculosis Research. Published Online September 2014 in SciRes.

Helper, Sahat P Manalu. (2011). Faktor Sosial Budaya Yang Mempengaruhi Ketaatan Berobat Penderita TB Paru di Kabupaten Tangerang. Puslitbag Ekologi dan Status Kesehatan. Jakarta Pusat.

Infodatin. (2015). Tuberkulosis; Temukan Obat Sampe Sembuh. .Pusat Data Dan Informasi Kementerian RI.
Kemenkes RI, (2014). Pedoman Nasional Pengendalian Tuberkulosis. Direktorat Jandral Pengendalian Penyakit Dan Penyehatan Lingkungan.

Muture. B. N. et al. (2011). Factors associated with default from treatment among tuberculosis patients in nairobi province, Kenya: A case control study. BMC Public Health 2011.

Moleong, Lexy J., (2014). Metodologi Penelitian Kualitatif. Bandung: PT Remaja Rosdakarya.

Pare (2013). Hubungan Antara Pekerjaan, Pmo, Pelayanan Kesehatan, Dukungan Keluarga Dan Diskriminasi Dengan Perilaku Berobat Pasien Tb Paru

PDPI., (2014). Pedoman Penatalaksanaan Tb (Konsensus TB ). Pedoman Diagnosis \& Penatalaksanaan Tuberkulosis di Indonesia.

Prayogo., (2013). Factor-faktor yang mempengaruhi kepatuhan minum obat anti tuberculosis pada pasien tuberculosis paru di puskesmas pamulang kota tangerang selatan propinsi banten periode januari 2012 januari 2013.

Pusdatin. (2015). Tuberkulosis; Temukan Obat Sampe Sembuh. Pusat Data Dan Informasi Kementerian RI.

Rikesdas., (2013). Riset Kesehatan Dasar. Badan Penelitian dan Pengembangan Kesehatan Kesehatan RI tahun 2013.

Rian S. (2010). Pengaruh Efek Samping Obat Anti Tuberkulosis Terhadap Kejadian Default Di Rumah Sakit Islam Pondok Kopi Jakarta Timur Januari 2008-Mei 2010.

Sangadah., (2012). Analisis factor penyebab terputusnya pengobatan tuberculosisi parudiwilayah kerja dinas kesehatan kabupaten kebumen

Santha. T. Et al., (2000). Risk factors with default, failure and death among tuberculosis patients treated in a DOTS programme in Tiruvallur District, South India. Pudmed article.

Saryono. M. D \& Anggraeni., (2013). Metdologi Penelitian Kuantitatif dan 
Kualitatif dalam Bidang Kesehatan. Yogyakarta: Nuha Medika

Slama. K. Et al., (2013). Factors associated with treatment default by tuberculosis patients in Fez, Moro

Steubert, Helen J \& Carpenter, Dona R. (2003). Qualitative Research in Nursing: Advancing the Humanistik Imperative. $3^{\text {rd }}$ Ed. Philadelphia: Lippincott William Wilkins.

Stuart, Gail Wiscarz. Sundeen, Sandra J. (2000). Principle and Practice Psychiatric Nursing. $6^{\text {Th }}$ Edition. St Louis. Mosby Yearbook.

Sugiyono., (2013). Metode Penelitian Pendidikan (Pendekatan Kuantitatif, Kualitatif, dan R\&D). Bandung : Alfabeta

Susilowati, (2012). Hubungan pengetahuan pasien tbc tentang penyakit tbc dengan kepatuhan minum obat anti tuberkulosis (OAT).

Kemenkes RI, (2014). Pedoman Nasional Pengendalian Tuberkulosis. Direktorat Jandral Pengendalian Penyakit Dan Penyehatan Lingkungan.

Kemenkes RI., (2013). Pedoman Nasional Pelayanan Kedokteran. Tatalaksana Tuberkulosis. 